\title{
THE EXPERIENCES OF FIRST-TIME MOTHERS WITH COLIC INFANTS WHO SEEK HELP FROM MEDICAL PROFESSIONALS
}

\section{Leigh Cox}

BNurs (Wits), MCur (RAU), Psychology Honours (UNISA)

\author{
Prof Vera Roos \\ D Phil (Psychology) \\ Professor, School for Psycho-Social Behavioural Sciences, Psychology, North-West University, Potchefstroom \\ Corresponding author:Vera.Roos@nwu.ac.za
}

Keywords: infant colic; first-time mothers; parent-infant relationship; psychological support

\begin{abstract}
The purpose of this study was to describe the experiences of first-time mothers with colic infants. The research design was qualitative, exploratory, descriptive and contextual. Data were collected by means of in-depth, semistructured, phenomenological interviews and a descriptive analysis was done. The results show that the real experience of having a baby did not meet mothers' expectations. Furthermore, colic babies were anxiety-provoking and mothers struggled with feelings of failure. They searched for an explanation for the colic, but felt disillusioned with the medical profession. Mothers exhibited a need for a containing figure. They also reflected on their relationship with their mothers. Mothers felt ambivalent towards their babies and marital relationships became strained. Lastly, mothers renegotiated their identity. Based on the results, suggestions for mental health professions were made with regard to providing parent-child therapy, support for the mother and strengthening the marital relationship. The importance of psychological interventions was emphasised as a source of support for these mothers.
\end{abstract}

\section{OPSOMMING}

Die doel van hierdie studie was om die ervarings van eerstekeermoeders met koliekbabas te beskryf. Die navorsingsontwerp was kwalitatief, ondersoekend, beskrywend en kontekstueel van aard. Data is ingesamel deur middel van indiepte, semi-gestruktureerde, fenomenologiese onderhoude en ' $n$ beskrywende ontleding is gedoen. Die resultate het getoon dat die beleefde ervarings om 'n koliekbaba te hê, nie aan die moeders se verwagtinge voldoen het nie. Voorts veroorsaak koliekbabas angs en moeders stry teen gevoelens van mislukking. In hul soeke na 'n verklaring vir die koliek, voel hulle ontnugter met die mediese professie. Moeders het ' $n$ behoefte aan ' $n$ ondersteunende persoon uitgedruk en gereflekteer op hul verhouding met hulle eie ma's. Moeders het ambivalent oor hul babas gevoel en hul huweliksverhoudings het gespanne geword. Laastens het moeders hulle identiteit as moeders heroorweeg. Op grond van die resultate word voorstelle vir professionele geestesgesondheidwerkers met betrekking tot ouer-kindterapie, ondersteuning aan die moeder en versterking van die huweliksverhouding, gemaak. Laastens word die belangrikheid van sielkundige intervensies in die hantering van koliek as ' $n$ hulpbron vir hierdie moeders beklemtoon. 


\section{INTRODUCTION}

In Western societies, colic or persistent infant crying in the early months is one of the most frequent clinical complaints for which parents seek professional help (Lindberg, 2000:1). Despite many studies on early infant crying and its impact on parents, there remains considerable debate over the definition, aetiology and consequences of colic (Maxted, Dickstein, MillerLoncar, High, Spritz, Liu \& Lester, 2005:58). A lack of coherence in the definition, as well as other methodological limitations, have contributed to research findings that are often unclear, contradictory and unconvincing (Long \& Johnson, 2001:156). Wessel, Cobb, Jackson, Harris and Detwiler (1954:425-426) define colic as fussing or crying in an otherwise healthy infant for "at least three hours a day, on three days a week, for at least three consecutive weeks". Colic typically occurs when the infant is approximately two to three weeks old, tends to peak in intensity around six weeks and normally resolves around four months (St James-Roberts \& Conroy, 2005:314). Since this study aimed to explore the subjective experiences of firsttime mothers who seek medical help for their excessively crying infants (who might not necessarily have been diagnosed as having colic), the definition of colic will be determined by the parents' threshold for infant crying.

Colic has been thought to be a consequence of an organic disturbance that results in gastrointestinal pain. However, a recent review of the literature concludes that organic disturbances, including lactose intolerance, only account for one in 10 colic babies and one in 100 babies overall (St James-Roberts \& Conroy, 2005:314). Another account views colic as behaviour that cannot be tolerated by the caregiver, suggesting a poorness of fit between infant and parent characteristics (Pauli-Pott, Becker, Mertesacker \& Beckmann, 2000:125). A third and seemingly leading explanation is that it is the result of neurodevelopmental changes that normally take place in early infancy, and that infants who cry often are assumed to be at the extreme end of the normal distribution of the crying curve (St James-Roberts \& Conroy, 2005: 314). However, Barr (1990:362) states that normalising colic deflects clinical attention from managing the sometimes serious effects of colic on the family. Indeed colic has been associated with parent fatigue, depression (St James-Roberts, Conroy \& Wilsher, 1996:375) and disrupted family life (Long \& Johnson, 2001:155). More rarely, it results in the clinical phenomenon of the shaken-baby syndrome (Morris, Smith, Cressman \& Ancheta, 2000:549). In a minority of cases, it leads to serious and prolonged disturbances in parent-child interaction and child development (Papoušek \& Von Hofacker, 1998:395).

Notwithstanding the lack of clarity on colic and the challenges this has posed for research, studies have found infant colic to be associated with disrupted family life, feelings of guilt, concerns about losing control and repeated cycles of hope and disappointment in searching for a cure (Long \& Johnson, 2001:155). Research by Stifter, Bono and Spinrad (2003:309) found that mothers may have more difficulty in dealing with an infant who exhibits excesses in crying at six weeks if the mothers display low interpersonal affect, if the stress of having a colicky baby is combined with poor marital relations, if there is poor family support and if the husbands do not provide adequate physical support in caring for their crying infants. Furthermore, research by Maxted et al. (2005:57) found that severely depressed mothers of colicky babies show greater parenting stress, poorer self-esteem and family functioning.

In the light of the above, the occurrence of colic in the early weeks of an infant's life is a problem of great complexity, with parent and infant characteristics seemingly contributing in varying degrees to the experience. However, only a few descriptive studies have been conducted to understand colic from mothers' and families' perspectives (Long \& Johnson, 2001:156; Wade, Black \& Ward-Smith, 2005:352).Thus, the purpose of this study was firstly to describe the experiences of first-time mothers with colic infants. The second purpose was to explore the implications of the findings for mental health practitioners and to make recommendations for providing psychological support for these mothers. The findings from this research could be used to provide insight into ways of preventing mental health problems by supporting mothers so that they can cope with their colic infants. Such interventions may promote child development and strengthen marital relationships during a very challenging period of the relationship. 


\section{METHOD}

\section{Research design}

The design was qualitative, exploratory, descriptive and contextual (McLeod, 2001:54-56). The aim was to explore and provide a dense description of the experiences of first-time mothers with colic infants within the context in which the experience takes place (Giorgi \& Giorgi, 2003:27). The research was inductive, allowing meaning to be established with respect to how firsttime mothers with colic infants make sense of their lives, experiences and the structures of their world (McLeod, 2001:38).

\section{Research context and sampling}

The participants were first-time mothers who became sufficiently distressed by their infants' crying to seek medical or paramedical help. The mothers presented at public and private medical facilities, pharmacy clinics and/or paramedical professionals such as physiotherapists. Purposive sampling was used to select participants who met the following sampling criteria:

- The sample included only first-time mothers, given that a prior experience of motherhood is likely to colour one's experience of a second baby who is colicky.

- Mothers sought help from medical professionals, primarily for their infant's crying. Since the study defined colic in terms of the parents' threshold for infant crying, it was not known whether or not the infants of the mothers who participated in this study actually met the most commonly used diagnostic criteria for colic (see Wessel et al. 1954:425-426).

- The infants were between the ages of 0 and 12 months. Mothers of older infants were included because in the researcher's experience, mothers in the midst of coping with a colic baby often do not have the reserves to participate in a research study.

- The participants were all conversant in English.

In addition to the sampling criteria, participants were all urban, white, married, professional women between the ages of 25 and 35 years.

\section{Data collection and analysis}

Data were collected by means of in-depth semi-structured phenomenological interviews (Britten, 2000:11-19), which were recorded on a digital voice recorder and transcribed verbatim (Silverman, 2000:149-151). Each participant was interviewed once and the interview lasted between 60 and 75 minutes. The interview began in a fairly unstructured way, with more structured questions asked on topics that the interviewees did not raise themselves. The following opening question was asked: "As a first-time mother, could you tell me about your experiences of having a colic baby?" For the sake of clarity, the following topics were also addressed if they did not emerge spontaneously from the interview:

- Conception, pregnancy, birth and feeding history.

- What are your feelings and thoughts when your baby is crying inconsolably?

- What has enabled you to cope with your colicky baby; what has made it more difficult?

- Relationship with partner, spouse, previous and current health of marital relationship.

- Early and current history with own parents.

- Anticipation about the child's future, the mother's hopes and fears for her child.

Comprehensive field notes were taken and analysed in relation to the interviews to help determine themes and categories.

The transcripts were analysed by the researcher and a process of peer debriefing (Lincoln \& Guba, 1995: 208) was used to probe the researcher's biases, explore meanings and clarify interpretations until data saturation (Giorgi \& Giorgi, 2003:31) was achieved. Data were analysed according to the descriptive analysis method suggested by Tesch (as quoted by Creswell, 1994:155). A literature control was conducted to compare and contrast the findings of this study, thereby ensuring trustworthiness (Frankel \& Devers, 2000:255).

\section{Trustworthiness}

Lincoln and Guba's (1995:301-328) criteria were used to ensure the trustworthiness of the research. In ensuring that credible findings and interpretations were produced the researcher allowed sufficient time to 
complete the research. She spent almost three years in the field, learned about the topic and emerged herself in the literature. She also had lengthy discussions about her own interest in the topic to become more aware of her "personal distortions," so that they did not interfere with the research process. The researcher also engaged in a process of persistent observation by completing a course in infant observation and was a member of a parent-infant psychotherapy reading group, in which the topic of the research was also discussed. A peer reviewer was used to ensure the credibility of the findings. The participants were also invited to do member checks of the initial findings. When required for clarity, additional information was obtained and integrated with the data. An audit trail of the data is available. Data were recorded and transcribed.

\section{Ethical considerations}

This study was part of a project entitled: "An exploration of enabling contexts" for which ethical permission was granted (\# 05K14), by the North-West University's Ethics Committee. The participants were informed about the research project and informed consent was obtained. They were also advised that they could withdraw at any point. Confidentiality and anonymity of the source material was maintained (SA Health Info, 1999:34-35). Participants were also followed up after the research and psychiatric and psychological referrals were given where necessary.

\section{DISCUSSION}

An integrated discussion of the findings follows, including quotations from the participants and support for the findings from the literature. The first category highlights mothers' unmet expectations of having a baby.

\section{The real versus the imagined experience of having a baby}

During pregnancy mothers develop ideas of their children and themselves as mothers, which, if balanced, provide the beginnings of an emotionally secure base for the baby (Cohen \& Slade, 2000:27). In this research, the real versus the imagined experience of having a baby did not met mothers' expectations, and left them feeling unprepared and out of control: "I thought it's going to be wonderful and I'm not going to have a crying baby, so when she came out and it was just this screaming all the time, I really had a rude awakening". Another participant confirmed her lack of control over the situation: "I had a lot of preconceived ideas of how I was going to bring this baby up, then he ended being colicky and I felt like burning the (parenting) book". Cohen and Slade (2000:21) report that numerous external and internal factors determine successful adaptation to pregnancy and motherhood. These include age, socioeconomic status, support systems, the ability to tolerate negative affect and ambivalence, as well as readiness to form balanced representations of the baby. A mother's sense of feeling out of control is both compounded by and contributes to significant levels of anxiety. This is discussed in the following section.

\section{A colic baby is anxiety-provoking}

Colic elicited anxieties about the baby being abnormal or ill: "I thought my baby is not normal, something is wrong". For most mothers, colic was inextricably linked to their infants' difficulty in tolerating the feed, resulting in mothers feeling anxious and ambivalent about the feed: "It's a vicious cycle; you feed him and it calms him for a few minutes and then he gets more cramps, then he screams some more, so you can't keep on feeding, but then he doesn't get enough food". Another mother reflected: "I just wished we didn't have to feed him". Several studies have shown that a colic baby makes a mother feel anxious (Papoušek \& Von Hofacker, 1998:395; Wade et al. 2005:352). Mothers also felt anxious about leaving their baby in the care of others: "Even though he is older, I still worry about the maid and the pool. I have only just started letting her bath him". Stifter and Bono (1998:339) found that mothers of colic infants display more separation anxiety than mothers who do not have to deal with colic babies.

\section{Feelings of failure}

Multiple attempts to soothe the baby, or to find an effective treatment, left the mothers feeling helpless and inadequate: "You feel helpless, you can see he's in pain, but you don't know what else to do". The participants' sense of inadequacy is captured in this description: "It was a sense of total ineffectiveness and now this child was not able to drink properly. He was arching his back, screaming, unhappy, in pain, he had wind, reflux and I thought l'm doing everything wrong". 
Stifter and Bono (1998:339) found that mothers of colic infants often feel less competent as mothers.

Over time, feelings of helplessness and inadequacy cause feelings of hopelessness and depression. This is linked to mothers' perception of colic as interminable and of themselves as impotent to effect change: "I felt that it would never end, the total utter helplessness to the point where you feel that you can't make this better and then losing hope that it would ever come to an end". "I reached breaking point and I gave up - this feeling of, 'I can't do anymore for you". Maxted et al. (2005:56) found that moderate to severe depressive symptoms were reported by $42.5 \%$ of mothers with a colic infant, which ultimately places the parent-infant relationship at risk.

Several of the mothers in this study had a stressful labour and/or delivery, which left them feeling emotionally vulnerable and compounded their sense of failure: "The birth was traumatic I was in a lot of pain. The first day, it's true what they say about post baby blues. I was bad, I couldn't hold him, I couldn't do anything". Papoušek and Von Hofacker (1998:415) found that prenatal stress and anxiety might prevent a mother from developing self-confidence.

In the midst of grappling with issues of competency, many mothers perceived some of the advice given by medical professionals, family and friends as a judgement on their ability as a mother: "Then it's the comments from people, from the paediatrician to my friends. There were times when we went to visit them and looked exhausted and they would say that you could take an antidepressant if YOU'RE not coping. You feel so frustrated because you're trying to explain that anyone in your situation wouldn't be coping". "I just felt nobody understood where I was coming from, what I was experiencing and what my child was really like". These quotations reflect Long and Johnson's (2001:160) finding that mothers of colic babies experience a different kind of social isolation characterised by a lack of understanding and empathy.

However, for many of the participants, anxieties about failure also undermined their ability to accept support: "I think it's a fear of admitting failure. You know that sleep deprivation can change your personality but you think if I do get a night nurse, that you're admitting that you can't cope". Such an approach reduced mothers' access to emotional and instrumental support, which bolsters a mother's self-efficacy and reduces completing tasks. Consequently, her ability to remain engaged and sensitively responsive to her baby is impeded (Crockenberg \& Leerkes, 2000:74). Mothers of colic babies often experience that their infants are unresponsive to their best efforts to soothe it. The following quote illustrates the participant's recall of a moment when they did perceive their baby as responsive, and reflects the mothers' need for affirmation from the baby: "When they brought him he was crying and when I spoke to him he just stopped. That was the best part, he recognised my voice". Stifter and Bono (1998:347) state that the basis of maternal self-efficacy is rooted in a mother's ability to respond with success to her infant's needs, a task that is enormously difficult with colic infants, who are generally inconsolable. In the face of high levels of anxiety and concern about their competency as a mother, the participants employed various psychological defence mechanisms to ward off anxiety and maintain self-esteem. Most commonly, mothers intellectualised their experience: "I kept saying to people that it was because he was premature, this is normal and it will be fine". They also split off and suppressed or repressed painful affect: "I felt this numb frozen feeling looking at him while he was screaming" and focused on the instrumental aspects of mothering: "You carry on like a robot dealing with the next non-sleeping, non-eating and fussiness".

\section{Search for an explanation for the colic}

The mothers' search for information on the causes of and treatment for colic offered hope that understanding and control could be gained: "We started our cycle of chiropractors, reflexologists, homeopaths, medication for reflux; we changed his formula a hundred times; we have a hundred bottles, a hundred teats; it was this desperate clinging to something". However, in the search for a cure, conflicting information and advice left the mothers feeling anxious and overwhelmed. One participant recommended: "Ask one person. I asked everyone - 'help"'. But at a stage there was too many things. You just couldn't cope." Long and Johnson (2001:158) agree that advice offered by medical personnel may be experienced as pejorative.

Most mothers view medical and/or psychological 
factors as possible causes of or contributing factors to colic, a belief supported by Long and Johnson (2001:158). Medical factors may include prematurity, lactose intolerance, and labour and birth complications, while stress during the pregnancy may be a psychological factor. With regards to the latter, mothers struggle with feelings of guilt that stressors during their pregnancy may have contributed to their baby's colic: "I blame myself, because I studied. Sometimes I feel like that stress brought this on". Furthermore, colic is seen as a punishment for perceived wrongdoings during pregnancy. One mother whose pregnancy was unplanned and unwanted said: "I felt like I brought this upon him in some way, this (colic) was kind of my compensation for him to give him more". Interestingly, Wurmser, Rieger, Domogalla, Kahnt, Buchwald, Kowatsch, Kuehnert, Buske-Kirschbaum, Papoušek, Pirke and Von Voss, (2006:341) found that prenatal life stress is associated with infant crying and fussing. However, St James-Roberts and Conroy (2005:313) caution that given the problems that have dogged colic research, researchers must be sure of their grounds before making such a claim.

\section{Disillusionment with medical profession and personnel}

The mothers perceived medical personnel as insufficiently supportive and sometimes dismissive of their concerns: "He wasn't latching properly, he was tiny, he was underweight, and I'm a new mommy and they sent me home". Another mother reported: "I think there was a lack of communication from the doctor's side". Most mothers felt disappointed that a cure for colic has not been found: "With all the technology, I cannot understand how they still don't know how to manage colic".

\section{Need for a containing figure}

The experience appeared to break down the mothers' psychological defences, bringing to the fore vulnerabilities and the need to be mothered and contained themselves: "What helped was my midwife. Although I'm a logical person, when you're so sleep deprived, you can't even think for yourself; you need somebody literally to hold your hand". Husbands also functioned as an emotional container: "When he walked in here you would just feel better". Mothers also felt that practical support was helpful: "I had a great support system with friends and family, so people helped and cooked meals". Long and Johnson (2001:159) note that mothers with colic infants need someone to visit and 'be there'. Winnicott (1964:113) highlighted the role of the father in providing safety and containment for the mother, allowing her to relax her psychological boundaries so as to become attuned to her infant's needs. Some mothers perceived their own mothers as anxious, struggling to contain their daughters' anxieties and prompting the need for a substitute containing mother figure: "I found my mom, I don't know whether it's because she last changed nappies when we were small, but she didn't have the confidence. My sister just carried on with it".

\section{Mothers reflect on their mothers as women and mothers}

During pregnancy, a woman's experience of herself as a child in relation to her mother hopefully gives way to identification with her mother, often allowing women to see their mothers in a more positive light (Cohen \& Slade, 2000:27). In line with this, the participants' identification with their mothers resulted in a new understanding of them and of the mother-daughter relationship: "You actually realise for the first time how much your mother loves you, that they had to go through this process. It gives you a lot of humility. You respect and understand women a lot better and it's an added relationship that you have with your mother - she's now a grandmother and you're now the mother". Furthermore, mothers drew on their perception of their childhood experiences of their mothers as positive or negative role models of parenting. The following quote provides an example of a positive role model: "I am going to try and be like my mom was - give my children so much love and attention like she did". However, some participants tended to idealise their mothers as a psychological defence to resolve possible emotional conflict and ward off anxieties around this relationship: "My mother is wonderful - what she taught me I would like to teach her". Later when asked what it was about her mother that made her such a good parent she replied: "I don't know, just everything". This defence may place pressure on mothers to live up to what may be an idealised example of parenting. With regards to negative role models, a mother who had been left to cry in a locked room as a young child said: "So now as 
soon as she starts crying I try and pick her up and try and calm her". Stern (1995:28) notes that through modelling, identification and internalisation, women ultimately learn how to mother from their mothers, for good or ill. Although a detailed analysis of these processes is beyond the scope of this study, it is important to note that mothers' working models of relationships, based in part on their own childhood experiences with parents, affect their perceptions of infant emotions and their interpretations of their infants' behaviour (Crockenberg \& Leerkes, 2000:72).

\section{Ambivalence towards the baby}

For Winnicott (1964:25), the quality of the mother's provision of infant care is based on empathy, or the mother's ability to feel her way into her child's experience. In this study, most mothers demonstrated empathy for their babies: "It's terrible to see her in pain". Another described it as "having really bad heartburn". However, they also perceive their babies as demanding and endlessly needy: "Twenty-four hours I need to look after him. He was crying and screaming the whole time unless you hold him". Thus, the mothers were left feeling at the mercy of and controlled by the baby: "Movement consoled him, so as long as you were prepared to jog up and down 24 hours a day it would help, but the minute you stopped he would wake up and start screaming". Consequently, mothers experienced physical, emotional and behavioural symptoms associated with fatigue and exhaustion: "I think I am tired; I struggle to get up; I am always late; it is as if I am slow".

Several mothers perceived their baby as intrinsically difficult, resulting in feelings of disappointment in the baby. In comparing her experience to mothers who are perceived as having easier babies, one mother commented: "I sometimes felt, ooh, I wish that was me, but this is your child and you have to accept what you've got'. Several participants perceived their babies as rejecting: "Sometimes I felt like even if I was with him the whole day and he was crying, then his dad comes in and he might just relax a little bit more, I would notice it and that would hurt me". Although it is no longer accepted that colic exists purely in the eye of the beholder or that factors related to parental care cause persistent crying (Papoušek \& Von Hofacker 1998:413). Pauli-Pott et al. (2000:130) found that the babies of some mothers who sought medical help for their infants' crying did not meet the criteria for colic (for example, fussing or crying in an otherwise healthy infant for "at least three hours a day, on three days a week, for at least three consecutive weeks") (Wessel et al. 1954:425-426). This suggests that there are psychological or cultural factors involved. Thus, the potential risk to the parent-infant relationship seems to lie in the stressful dynamic between parent and infant factors (Stifter et al. 2003:309).

Following this, many participants spoke of feelings of rage towards the baby, resulting in fears of losing control and harming or abandoning the baby: "There were times when you want to throw him against the wall". Another participant said that she sometimes felt like "running away". Long and Johnson (2001:158) echo this finding. The participants felt that these negative feelings towards the baby impacted on their empathy and bonding with the baby: "It impacts on bonding with your child". "It's the stress of the relentless screaming. Initially you have sympathy, then it just becomes too annoying to bear. You start thinking that I need to stop this because I now can't stand it'. These negative feelings towards the baby and the perceived consequences resulted in feelings of shame and guilt: "There are times when you feel: 'Leave me alone, I don't even want to hold you', and then you feel so bad". Stifter and Bono (1998:341) state that if mothers continue to perceive their infants as difficult even after the colic has resolved, the attachment relationship may be negatively affected. In this category, several psychological defence mechanisms were used to ward off anxiety and maintain self-esteem, such as minimising the perception of the baby as demanding, needy or intrinsically difficult: "Maybe he wasn't as bad as some of the stories you hear". Most of the mothers displaced their angry feelings onto their husbands: "You take it out on people around you. l'd fight with my husband". Long and Johnson (2001:159) also found that husbands are used as a figure on whom the mothers' emotions were displaced.

\section{Strained marital relations}

The participants perceived the colic baby as a source of stress in the couple's relationship. Most felt that the primary position the baby assumes in their mind creates distance in the couple's relationship: "It was just about the baby so we lived past each other", although some described the baby as an intruder in the couple's rela- 
tionship: "She's really time-consuming and I am looking forward to her not sleeping in our bed". Conflict also occurred as a result of the mothers' perception of their husbands as abdicating responsibility due to work pressures and/or their inability to cope with the baby, leaving mothers feeling primarily responsible for the baby: "He does try and help, but because he's working it's been mainly me. I reached a limit where I said to him 'It's not just my responsibility, I didn't want her all on my own, I'm not a single parent'". Another participant said: "My husband wasn't very good with his screaming because he didn't know how to handle it, so I was basically the only one". Thus mothers perceived their husbands' lives as less disrupted by the baby, leading to feelings of resentment: "So he still goes out shopping with his friends, then I get a bit anxious because I'm sitting at home babysitting, so I don't think it's fair". Several studies have shown that families with colic infants experience high levels of anxiety and marital conflict (Long \& Johnson, 2001: 157; Räihä, Lehtonen \& Korvenranta, 1995:206).

\section{Mothers renegotiate their identity as a woman and mother}

In becoming a mother, every aspect of a woman's sense of self is reworked. In the last weeks of pregnancy and in the early months following an infant's birth, a mother needs to surrender herself to her baby, while maintaining an autonomous identity (Cohen \& Slade, 2000:28). Participants experienced this loosening of boundaries that results in the mothering role to be all-consuming, and felt keenly the loss of a psychological identity that was separate from the baby: "You, as anything more than a mother, takes a backseat. There was no differentiation of me as a person". Although Winnicott (1964:20) refers to this 'primary maternal preoccupation' as a requirement for mothers to do what they need to do for their baby, it appears that initially, the physical and emotional demands associated with a colic baby may impact on a mother's ability to maintain a separate psychological self while simultaneously merging with the baby. Mothers also found their self-image challenged: "I never thought I wouldn't cope" and they mourned the loss of a previous identity and lifestyle: "Sometimes I just wanted my old life back". Over time, most of the mothers seemed to re-establish their boundaries, allowing for a separate psychological space from the baby: "I now allow space for myself, for my thoughts and feelings". The move from a unitary sense of self to an identity that encompasses a child involves instability and then reintegration as new structures of self are formed (Cohen \& Slade, 2000:27).

\section{CLINICAL IMPLICATIONS FOR THE MEN- TAL HEALTH PRACTITIONER}

The findings suggest that colic poses a potential threat to the parent-infant relationship and may be a major risk for the infant's development. With the focus of treatment shifting from curing to preventing mental health problems, parent-infant therapy, individual supportive counselling and couple's counselling could be provided as support for first-time mothers with colic infants. Parent-infant therapy utilises combined work with parents and infants to improve parent-child relationships and child development (Lieberman, Silverman \& Pawl, 2000:483). It addresses both conscious and unconscious factors that shape parent and infant interactions (Baradon \& Joyce, 2005:25). According to Baradon and Joyce (2005:25), interventions may focus either on enhancing parent functioning in relation to the infant, or on promoting the infant's development. Regarding the former, Baradon and Joyce (2005:25-26) describe the following objectives:

- To help parents reflect on states of mind in themselves, in their infant and in their relationship.

- $\quad$ To help parents regulate their own and their infant's emotional states, given that emotional regulation is an essential component of development.

- To help parents recognise their infant as a dependent person with a developing mind. This may require helping parents to cope with infants' initial dependency and later manage the process of separation-individuation.

- To interrupt the repetition of negative intergenerational patterns of relating.

- To facilitate the couple's parenting of the baby given that coupled collaborative parenting between mother and father supports the infant's development.

Other factors that impact on a mother's capacity to adapt successfully to motherhood, and which could be included in individual, supportive counselling, are an openness to becoming a mother, the capacity to tolerate negative affect and ambivalence, readiness to form 
secure and balanced representations of her baby and the degree to which she has herself developed mature object relations and achieved a degree of security, flexibility and autonomy from her own parents (Cohen \& Slade, 2000: 21).

The infants are also important contributors to the relationship with their parents. Their "warm soft skin, smell, intense gaze, their unique openness and appetite for primordial connection" (Joyce, 2005:13) evoke the most intense and profound feelings in their parents and in other adults alike. Furthermore, their in-built developmental programme, physical health, temperament and developmental stage all interact with and shape the parent's perceptions, distortions and projections to create definitive and sometimes selfperpetuating patterns of maladaptive relationships, and therefore should be the focus in parent-child therapy. Aims that focus on the infant address interactions on the infant's part that may compromise the parent-infant relationship, such as encouraging a baby to re-engage with a parent who may have been withdrawn or intrusive. In extreme cases, the mental health practitioner may need to work towards the provision of alternative care for the baby (Baradon \& Joyce, 2005:25-26).

The last implication of this research is that parents and babies live within a wider familial and social network that informs their culture, class and religious associations. Thus the degree of isolation or integration within culture and community, partner relationship, socioeconomic status and degree of social supports all impact on the infant-parent relationship (Cohen \& Slade, 2000;21; Joyce, 2005:25-26), and should be addressed in supporting the infant and its parents in dealing with colic.

\section{LIMITATIONS}

The study only utilised one method of data collection. Including additional methods such as focus groups may have allowed for further confirmation that all aspects of the phenomenon were tapped.

\section{RECOMMENDATIONS}

The results highlight the need for the inclusion of a psychological approach as a resource for first-time mothers with colic infants. As such, information should be provided to mental health professionals about the importance of including psychological support in dealing with colic. Parent-infant therapy, couple's and individual counselling could be included in tertiary education curricula; and transdisciplinary interventions should be promoted. Further research could be conducted with respect to the unconscious processes that mediate the experiences of first-time mothers with colic infants, and on the effectiveness of parent-infant therapy in providing psychological support to first-time mothers with colic infants.

\section{CONCLUSION}

The results of this study confirm how stressful the period of colic is for first-time mothers, and indeed for the couple's relationship. This, together with the other difficulties highlighted in the study, may pose a significant risk to the parent-infant relationship and to child development. The problems inherent in adopting an exclusively medical approach to the treatment of colic were also highlighted, and call for the inclusion of psychological interventions as a resource for first-time mothers with colic infants.

\section{REFERENCES}

BARADON, T \& JOYCE, A 2005: The theory of psychoanalytic parent-infant psychotherapy. (In: Baradon, T ed. 2005: The practice of psychoanalytic parent-infant psychotherapy: Claiming the baby. London: Routledge, pp 24-40).

BARR, RG 1990: The normal crying curve: What do we really know? Developmental Medicine and Child Neurology, 32(4):365-362.

BRITTEN, N 2000: Qualitative interviews in health research. (In: Pope, C \& Mays, N eds. 2000: Qualitative research in health care; $2^{\text {nd }}$ edition. London: BMJ Books, pp 11-19).

COHEN, LJ \& SLADE, A 2000: The psychology and psychopathology of pregnancy: Reorganisation and transformation. (In: Zeanah, CH ed. 2000: Handbook of infant mental health; $2^{\text {nd }}$ edition. New York: Guilford, pp 20-36).

CRESWELL, JW 1994: Research design: Qualitative and quantitative approaches. London: Sage.

CROCKENBERG, S \& LEERKES, E 2000: Infant social and emotional development in family context. (In: Zeanah, $\mathrm{CH}$ ed. 2000: Handbook of infant mental health; $2^{\text {nd }}$ edition. New York: Guilford, pp 60-90).

FRANKEL, RM \& DEVERS, KJ 2000: Study design in qualitative research -1 : Developing questions and assessing resource needs. 
Education for Health, 13(2):251-261.

GIORGI, A\& GIORGI, B 2003: Phenomenology. (In: Smith, JA ed. 2003: Qualitative psychology: A practical guide to research methods. London: Sage, pp 25-50).

JOYCE, A 2005: The parent-infant relationship and infant mental health. (In: Baradon, T ed. 2005: The practice of psychoanalytic parent-infant psychotherapy: Claiming the baby. London: Routledge, pp. 5-24).

LIEBERMAN, A, SILVERMAN, R \& PAWL, JH 2000: Infant-parent psychotherapy: Core concepts and current approaches. (In: Zeanah, $\mathrm{CH}$ ed. Handbook of infant mental health; $2^{\text {nd }}$ edition. New York: Guilford, pp 472-484).

LINCOLN, YS \& GUBA, EG 1995: Naturalistic Inquiry. Newbury Park: Sage.

LINDBERG, L 2000: Infantile colic: Aetiology and prognosis. Acta Paediatrics, 89(1):1-2.

LONG, T \& JOHNSON, M 2001: Living and coping with excessive infantile crying. Journal of Advanced Nursing, 34(2):155-162. MAXTED, AE; DICKSTEIN, S; MILLER-LONCAR, C; HIGH, P; SPRITZ, B; LIU, J \& LESTER, BM 2005: Infant colic and maternal depression. Infant Mental Health Journal, 26(1):56-68.

MCLEOD, J 2001: Qualitative research in counselling and psychotherapy. London: Sage.

MORRIS, MW; SMITH, S; CRESSMAN, J \& ANCHETA, J 2000: Evaluation of infants with subdural hematoma who lack external evidence of abuse. Pediatrics, 105(3):549-553.

PAPOUŠEK, M \& VON HOFACKER, N 1998: Persistent crying in early infancy: A non-trivial condition of risk for the developing mother-infant relationship. Child: Care Health and Development, 24(5):394-424.

PAULI-POTT, K; BECKER, K; MERTESACKER, T\& BECKMANN, D 2000: Infants with "colic" - Mothers' perspectives on the crying problem. Journal of Psychosomatic Research, 48:125-132. RÄIHA, H; LEHTONEN, L\& KORVENRANTA, H 1995: Family context of infantile colic. Infant Mental Health Journal, 16(3):206-217. SA HEALTH INFO 1999: Ethics issues in qualitative research. http:/ /www.sahealthinfo.org/ethics/ethicsqualitative.htm (Accessed: 5 April 2006).

SILVERMAN, D 2000: Doing qualitative research: A practical handbook. London: Sage.

ST JAMES-ROBERTS, I; CONROY, S \& WILSHER, K 1996: Bases for maternal reports of persistent infant crying and colic behaviour. Archives of Childhood Disease, 75:375-384.

ST JAMES-ROBERTS, I \& CONROY, S 2005: Do pregnancy and childbirth adversities predict infant crying and colic? Findings and recommendations. Neuroscience and Biobehavioural reviews, 29:313-320.

STERN, DN 1995: The motherhood constellation: A unified view of parent-infant psychotherapy. New York: Basic Books.
STIFTER, CA \& BONO, M 1998: The effect of infant colic on maternal self-perceptions and mother-infant attachment. Child: Care, Health and Development, 24(5):339-351.

STIFTER, CA; BONO, M \& SPINRAD, TL 2003: Parent characteristics and conceptualisations associated with the emergence of infant colic. Journal of Reproductive and Infant Psychology, 21(4):309-322.

WADE, K; BLACK, A \& WARD-SMITH, P 2005: How mothers respond to their crying infant. Journal of Paediatric Health care, 19(6):347-353.

WESSEL, MA; COBB, JC; JACKSON, EB; HARRIS, GS \& DETWILER, AC 1954: Paroxysmal fussing in infancy: Sometimes called 'colic'. Paediatrics, 14(5):424-434.

WINNICOTT, DW 1964: The child, the family and the outside world. Middlesex: Penguin.

WURMSER, H; RIEGER, M; DOMOGALLA, C; KAHNT, A; BUCHWALD, J; KOWATSCH, M; KUEHNERT, N; BUSKEKIRSCHBAUM, A; PAPOUŠEK, M; PIRKE, K \& VON VOSS, H 2006 : Association between life stress during pregnancy and infant crying in the first six months postpartum: A prospective longitudinal study. Early Human Development, 82(5):341-349. 